\title{
The Experience of Digitalization of the Housing and Utility Sector in Russian Regions
}

\author{
Vera I. Aleshnikova \\ Department of marketing \\ State University of Management \\ Moscow, Russia \\ manager.vsu@gmail.com
}

\author{
Nadezhda A. Anisimova \\ Department of digital and industry Economics \\ Voronezh State Technical University \\ Voronezh, Russia \\ b0lahd@mail.ru
}

\author{
Tatiana S. Narolina \\ Department of economic security \\ Voronezh State Technical University \\ Voronezh, Russia \\ narolina@inbox.ru \\ Tatiana I. Smotrova \\ Department of economic security \\ Voronezh State Technical University \\ Department of economic theory and world economy \\ Voronezh State University \\ Voronezh, Russia \\ s-tanik@yandex.ru
}

\begin{abstract}
The housing and utility sector in Russia is described by low efficiency, great number of managerial and technological problems. Implementation of the program «Digital economy in the Russian Federation» did not affect the scale of introduction of the digital technologies into this sector. The purpose of this study is the analysis of the experience of digital technology application in the housing and utility sector. Results: the main problems of housing and communal services and possible directions and areas of application of digital technologies for their solution are identified. The first direction is related to reducing the losses of supplied resources, implementing operational control and accounting for their consumption, and managing costs. The second aspect is the improvement of the tariff calculation procedure. The third direction is to generate up-to-date data on the volume and quality of services provided, the condition of an apartment building, and open interaction between management companies and homeowners. The fourth area lies in the development of tools for public control and ensuring access of owners and residents of the house to information about the work performed on the house and the local area. The best practices of digitalization of housing and communal services in the regions of Russia are systematized: in attracting housing self-government; automated remote control and control of energy consumption; digital duplicates of cities.
\end{abstract}

Keywords: digital economy, housing and utilities, utilities, smart city, smart technologies, tariff, efficiency

\section{INTRODUCTION}

In accordance with the theory of technological cycles, the current stage of the Russian economy development is characterized by the focus on the use of resource-saving and innovative technologies, digitalization of the economy. The flawless operation and transparency of the housing and utility services system are the priority areas of the country's socio-economic development, as they create the conditions for comfortable life and recreation for the population. The alteration of the approaches to housing management meets Russia's strategic guidelines and is based on the use of digital technologies that ensure the rational use of resources and energy efficiency, maximum public access to information concerning the operation of the facility management companies, and transparency in the formation of tariffs and financial flows.

The introduction of digital technologies in the housing and utility sector is focused on the observance of interests and is beneficial for all market participants (the state, facility management companies and partnerships of homeowners, the population). This is achieved due to the increased efficiency of horizontal and vertical communications among market participants due to the open architecture and API (application programming interface), the integration of information systems of various levels, and the increased accuracy of consumption accounting based on IoT (Internet of Things) technologies. By setting the development guidelines and digitalization targets, the state seeks to increase the economic and energy efficiency of the sector by systematizing the data and making informed decisions at all levels. Ultimately, this helps to improve the performance of the companies involved in the sector and reduce costs. For facility management companies and homeowners associations, the use of digital technologies can significantly improve the efficiency of management and operations, and the quality of services provided. For residents the emergence of various services makes it possible to get access to up-to-date information, participate in management through electronic voting and circulation system, and evaluate the quality of housing and utility services. Digitalization provides the population with complete transparency and correct charging.

However, experience shows that penetration of digital technologies in housing and utility sector is uneven, fragmented, and does not provide the expected positive results. The emergence of problems in the housing and 
utility services is associated with the lack of the regulatory framework, outdated management and organizational approaches, behavioral stereotypes of all market participants, including homeowners who are passively involved in the housing self-government procedure.

The effective use of digital technologies became possible due to the national projects implemented since 2018: «Housing and rural environment» [1] and «Digital economy» [2]. There the new bases for housing and utility sector management are formed. The amount of financing the national programme «Digital economy» in 2019-2024 is estimated as 1.8 trillion rubles, which proves the high chances for successful realization of the set priority targets. In March, 2019, the Ministry of construction approved the standards of «smart city», where housing and utility sector is one its elements. The standards will be introduces within five years for all settlements with the population number cxcecding 100 thousand pcoplc.

\section{Methodology}

A systematic approach was used as a methodological basis for the study of promising areas of application of digital technologies in the sphere of housing and communal services. The main methods were a comparative analysis of the regional practice of digitalization of housing and communal services in Russia, a method of expert assessments to identify housing problems. The study was verified on the basis of official documents of Rosstat, normative legal acts, state programs in the field of housing and communal services and the digital economy, and official websites of the subjects of the Russian Federation.

\section{DISCUSSION}

\section{A. The key problems of the housing and utility sector and the digital technologies for their solving}

Analysis of the academic literature $[3,4,5,6,7,8,9,10$, 11] allowed us to identify the problem field of housing and utility services for the significant number of the Russian regions:

- low veracity and transparency of the tariffs. According to experts $[12,13,14,15,16,17]$, the most pressing issue in the area of housing and utility services remains the procedure for setting tariffs for the services provided. The share of expenses for utility bills in different regions of Russia varies between $5.6 \%$ and $15.6 \%$ of the family budget, which is a considerable amount for a significant part of the population, especially the poor [18]. In addition to the high cost of housing and utility services for the population, the serious problem is:

- «low transparency» of the process of setting tariffs for the services provided and dissatisfaction with their quality;

- disordered and non-automated procedures for calculating the costs of works and services provided by resource-supplying and operating organizations;

- considerable energy losses in apartment blocks and the use of imperfect metering devices;
- complex procedure for checking the quality of provided utility services, sanitary services, repair and maintenance of apartment blocks, etc.;

- lack of public control over the quality of services provided, overhaul and maintenance, and the ability to form requests for necessary services;

- poor availability of information for the population and other market participants concerning the volume, cost, and timing of works and services;

- lack of effective system of interaction with the service consumers;

- poor activity of homeowners in the housing selfgoverning.

Thus, in the current conditions the key task is to ensure transparency of the mechanism for calculating the tariffs and their coordinating with residents, as well as the quality control procedures for the services provided. By the Order of the Government of the Russian Federation, target indicators have been set for ensuring the energy efficiency of the Russian economy, which in turn sets the task of reducing costs for the facility management companies.

The Ministry of Construction and Housing and Utility Services has added the Digital Facility Management Company project implemented by Megaphone to the «Smart city» decision bank. This is a system of inventory, accounting, and control of the utility services provision, the state of all types of energy resources, property complexes for the purpose of unification and the implementation of a uniform quality standard for the provision of services to owners of residential and non-residential premises. The system will use data collection technology through IoT. The access to the system for facility management companies and homeowners will be organized through a personal account.

Billing system based on SaaS platform for cloud computing is an adaptive and powerful software capable of supporting business-processes in housing and utility sector companies. The system works with large array of old data, which, when transferred to a new system, remain untouched and are not lost. The online system calculates payments for utilities and takes into account data on payment received and generates payment bills, thus ensuring transparency of financial transactions.

Integration of solutions in old housing assets may be organized by means of special controllers, free protocols, modems and interfaces, with the help of which (for example, from intercoms) it is possible to obtain not the complete information set, but only the part of it which will allow to detect a malfunction in time and send the responsible service organization to the facility.

Facility management company PIK-Comfort, a large private holding, unites several companies and operates in 18 regions (Moscow and the Moscow region, St. Petersburg, Ekaterinburg, Chelyabinsk, and others). It actively develops digital projects and creates its own IT solutions (IT product service «Inventory», «Inventory» service, «Dispatch» service, platform for litigation with debts). 


\section{B. Regional experience of housing and utility sector digitalization in Russia}

Analysts note that the process of implementing digital technologies is faced with the unpreparedness of the infrastructure of the housing and utility services to operate in the digital environment. By the end of 2018, the market for technological solutions for the "smart city" has grown by only $8 \%$, and it is almost completely concentrated in Moscow: the capital accounts for $93 \%$ of the market [19]

The process of digitalization of housing and utility services is accompanied by the reluctance of facility management companies to use automation tools due to their fears of the possibility of direct interaction between resource providers and residents, and as a result, loss of influence on the latter. It is important that the installation of new metering devices for the supplied resources requires serious funding and necessitates the formation of an appropriate mechanism. According to Rosstat, the level of penetration of information and communication technologies remains low: only $65 \%$ of resource-supplying companies use basic information technologies in their activities, while the use of information accounting systems is estimated at about $9 \%$ [20]. According to the survey among the regional authorities performed by the "Analytic Center» under the Government of the Russian Federation at the begimning of the second quarter of 2019 , the digitalization programme was adopted only in 23 regions, was being developed in 11 , and in 45 regions it is neither adopted nor under development [21]. Housing and utility sector and urban development, according to the survey, along with health care and education are among the highest priority areas. During 2019, the following regions greatly improved the operation of the geographic information system of the housing and utility sector: Republic of Tatarstan, Ryazan region, Kamchatka, Krasnoyarsk region, Murmansk region, and Chechen Republic. Still the leaders in this area are the following regions: Kostroma, Novosibirsk, and Omsk regions. Organizational work concerning information introduction into the geographic information system of the housing and utility sector is not properly completed in Ingushetia Republic, Crimea Republic, Kursk region, Dagestan Republic, and Perm region.

Our country implements regional and municipal programmes to improve the quality of services and improve the efficiency of housing and utility services. Digital technologies are also being developed that can automate the functions of forecasting and modeling, accounting for consumed resources, charging for services and receiving payments. Artificial intelligence technologies are being introduced to increase the efficiency of monitoring and managing infrastructure facilities. The models of «digital twins») allow one to keep track of and predict the repair of power grids.

Regional Uniform Information and Payment Centres (UIPC) have the ability to calculate and evaluate the economic effect in the implementation of digital technologies. For example, Municipal unitary company "UPC of HUS» of Domodedovo estimated the economic effect of MCTS metering equipment installation during the heating period of 2015-2016 in 275 apartment blocks in Domodedovo city district as 116 million rubles.
The digital platform of RIAS for housing and utility services was implemented in Ulyanovsk, Vladimir, Kirov and several other areas. This is a digital twin of the city, a system in which, in addition to cartographic data, information is stored from billing systems of the IPCs and facility management companies, data on the consumption of resources from dispatch systems, and the history of citizens' complaints and addresses. RIAS for housing and utility services allows control over the life cycle of the housing facility objects.

In Ulyanovsk, Dimitrovgrad, and Samara intellectual dispatch system «AIS City. Instrumental metering» was introduced. This AIS provides effective control of power resource consumption due to intellectual metering and automated remote control. The system has the potential for scaling.

In Moscow, the problem of participation in the housing self-government procedure, in particular, was discussed in October, 2019, in the crowdsourcing project «Electronic House». Eleven thousand people submitted about two thousand ideas (342 were hired) to improve the service, which allows performing the surveys of residents and tenants of the premises, general meetings of homeowners, and receiving information regarding their accommodation. To implement this opportunity, one needs to register in the «Active Citizen» application for computer or smartphone.

\section{CONCLUSION}

Summarizing the discussed above, we note that under the current conditions the use of digital technologies in housing and utility sector can solve a number of accumulated problems and significantly increase the efficiency of this branch of economy. At least four areas of their application in the housing and utility sector can be detected. The first one is associated with the reduction in the loss of supplied resources, the implementation of operational control and accounting for their consumption, and cost management. The second aspect is the improvement of the tariff calculation procedure. The third area is the formation of relevant data on the volume and quality of the services provided, the condition of the apartment blocks and the open interaction of facility management companies and homeowners. The fourth area lies in the field of developing the tools for public control and ensuring the access for the owners and residents of the house to the information on the work performed in the house and in the adjoining territory.

\section{References}

[1] "Housing and urban environment", National project [Electronic resource]. Available at: https://strategy24.ru/rf/citybuilding-and$\mathrm{jkh} /$ projects/natsiona-nyy-proyekt-zhil-ye-i-gorodskaya-sreda.

[2] "Digital economy of the Russian Federation", National program [Electronic resource]. Available at: http://government.ru/info/ 35568/.

[3] E.M. Akhmetshin, E.P. Solodova, and A.V. Selyutina, "Directions of Small Business Development in Housing and Communal Services of Samara Region", 31st International-Business-InformationManagement-Association Conference, Milan, Italy, 25-26 APR 2018, Innovation management and education excellence through vision 2020, vol. I-X, pp. 3924-3930, 2018.

[4] A. Dobrosavljević, S. Urošević, and G.V. Astratova, "Assessment of HR competencies in housing and communal utility services taking 
facilities and transport, EMMFT 2017, Book series: IOP Conference Series-Earth and Environmental Science, vol. 90, art. UNSP 012142, 2017.

[19] Rating of regions by the share of population spending on housing and communal services - 2018 [Electronic resource]. Available at: https://riarating.ru/regions/20180918/630105001.html.

[20] Smart housing: how government and business are changing the industry [Electronic resource]. Available at: https://www.vedomosti.ru/salesdepartment/2019/05/15/umnoe-zhkhkak-gosudarstvo-i-biznes-menyayut-otrasl.

[21] M.A. Sabelnikova, G.I. Abdrakhmanova, L.M. Gokhberg, O.Yu. Dudorova, and et al., "Information society in the Russian Federation. 2018: statistical collection", Rosstat, NATs. research, UN-t "Higher school of Economics", Moscow: HSE, 2018 [Electronic resource]. Available at: https://www.gks.ru/storage/ mediabank/info-ob2018.pdf.

[22] Analytical center under the government of the Russian Federation, Experts studied the development of digital technologies in the regions of the country [Electronic resource]. Available at: http://ac.gov.ru/events/023219.html.
[9] E.S. Kryukova, I.S. Povarov, and E.V. Ruzanova, "Issues of Effectiveness of Communal Service in View of Variability of Apartment Blocks Management System", Russia and the European union: development and perspectives, Book series: Contributions to Economics, pp. 9-16, 2017.

[10] O. Skrypnik, "Reform of housing-and-communal services at the federal, regional and municipal levels of management, as the basis of improvement of communication of the state and its population", International Science Conference SPBWOSCE-2016 - SMART CITY, vol. 106, 2017.

[11] E. Tshovrebov, E. Velichku, and A. Shevchenko, "Methodological Approaches to a Substantiation Resurso - and Energetically Effective Economic Model of Object of Placing of a Waste", 19th International Scientific Conference on Energy Management of Municipal Transportation Facilities and Transport, EMMFT, Far Eastern State Transport Univ, Khabarovsk, Russia, 10-13 April 2017, International Scientific Conference Energy Management of Municipal Transportation Facilities And Transport, EMMFT 2017, Book series: Advances in Intelligent Systems and Computing, vol. 692, pp. 1296-1305, 2018.

[12] "About the complex plan of actions for increase of energy efficiency of economy of the Russian Federation", Order of the Government of the Russian Federation of 19 April 2018, no. 703-p [Electronic resource]. Available at: https://base.garant.ru/71930276/.

[13] E.M. Maznitsa, E.R. Fiodorovykh, and S.V. Arkov, "Public-private partnership as basis of modernizationof the housing sphere of Russia”, 16th International Scientific Conference on Globalization and its Socio-Economic Consequences, Rajecke Teplice, Slovakia, 05-06 October 2016, 16th international scientific conference proceedings, pts I-V, pp. 1338-1346, 2016.

[14] S. Okhotina, P. Kukhtin, and L. Manukhina, "The method of complex evaluation of management in the sphere of housing and communal services", International Science Conference SPBWOSCE-2016 - SMART CITY, vol. 106, 2017.

[15] Y.V. Ragulina, E.I. Semenova, and I.A. Zueva, "Perspectives of solving the problems of regional development with the help of new internet technologies", Entrepreneurship and sustainability issues, vol. 5, iss. 4, pp. 890-898, June 2018.

[16] O. Skripnik, "Increase in competitiveness of housing-and-communal services", 19th International Scientific Conference on Energy Management of Municipal Iransportation Facilities and Iransport, EMMFT, Far Eastern State Transport Univ, Khabarovsk, Russia, 1013 April 2017, Energy management of municipal transportation facilities and transport, EMMFT 2017, Book series: IOP Conference Series-Earth and Environmental Science, vol. 90, art. UNSP 012144, 2017.

[18] O. Skripnik, "Management of reforming of housing-and-communal services", 19th International Scientific Conference on Energy Management of Municipal Transportation Facilities and Transport, EMMFT, Far Eastern State Transport Univ, Khabarovsk, Russia, 1013 April 2017, Energy management of municipal transportation 